\title{
ANCAMAN STRATEGI HYBRID WARFARE RUSIA: SEBUAH PERSEPSI DAN MANIFESTASI KEBIJAKAN ESTONIA
}

\author{
Dyah Lupita Sari \\ Magister Ilmu Hubungan Internasional, Universitas Indonesia \\ Email : dyah.lupita@gmail.com
}

\begin{abstract}
In recent years, Russia has developed a hybrid warfare strategy as a tactic to carry out war operations to achieve their national interests. Estonia is considered the most vulnerable country in the face of the threat of a Russian hybrid warfare strategy. In this case, Estonia has historical, geopolitical and political value for Russia. Estonia has received signs of the Russian threat manifested through their aggressive actions in Estonia with hybrid projections that have been projected in a real way. Thus, the Russian hybrid warfare strategy can influence the perception of the Estonian threat which was finally responded through a policy to stem the threat of hybrid itself. Underlying the analysis of the Threat Perception theory proposed by Raymond Cohen, this paper will explain how the Estonian threat is perceived by the Russian hybrid warfare strategy by looking at the threatening cue and responses to the threats. This paper has the argument that the hybrid warfare strategy is a threat to Estonia. The historical factor of Russian-Estonian relations and past experience of threats is a sign of a threat that influences the perception of Estonian threats. Estimation of the threat was then manifested by Estonia in the form of anticipatory actions through increased cooperation with NATO, an increase in Estonia's military capabilities, and other non-military approaches in counter Russian warfare hybrid strategy.
\end{abstract}

Keywords: Hybrid Warfare, Russia, Estonia, threat perception, threatening cue, asymmetric threat, cyber security, disinformation, NATO

\section{PENDAHULUAN}

Perubahan tatanan dunia setelah berakhirnya Perang Dingin tidak mengurangi pentingnya penggunaan kekuatan dan perang dalam studi Hubungan Internasional. Justru di era kontemporer, dinamika keamanan menjadi semakin kompleks akibat dari kemunculan aktor non negara yang dapat menjadi ancaman di masa depan. Negara-negara juga akan menerapkan strategi dan taktik yang dianggap paling efektif dalam menghadapi tantangan yang ada, khususnya terhadap ancaman asimetris. Penggunaan kekuatan asimetris tersebut yang akhirnya menjadi perdebatan dan dibahas dalam artikel ini melalui implementasi strategi hybrid warfare. Strategi hybrid warfare sendiri saat ini banyak dijadikan perdebatan baik di kalangan akademisi maupun militer Barat, khususnya sejak keberhasilan Rusia dalam menganeksasi Krimea tahun 2014 dalam konflik Ukraina. Melalui strategi hybrid warfare pula Rusia dapat memproyeksikan kepentingannya untuk memperluas pengaruhnya di kawasan, khususnya negara-negara bekas Soviet.

Estonia merupakan salah satu negara bekas Soviet di kawasan Baltik yang dianggap paling rentan terhadap ancaman hybrid warfare Rusia. Hal ini dikarenakan, 
Estonia adalah tetangga dekat dan memiliki makna politik dan ekonomi yang signifikan bagi Rusia. Pertama, dilihat dari posisi geografisnya, Estonia adalah negara anggota terluar dari NATO, sehingga negara ini merupakan manifestasi dari ekspansi NATO. Di saat yang sama, Rusia memandang ekspansi NATO sebagai sesuatu yang mengancam kepentingan geopolitik dan geostrategis Rusia (Karabeshkin \& Spechler, 2007:314). Kedua, Estonia memiliki sejarah pengaruh politik dan kultural Rusia yang kuat sehingga. Ketiga, Estonia memiliki entitas berbahasa Rusia yang cukup besar dan memanfaatkan retorika diskriminasi Estonia terhadap entitas tersebut sebagai justifikasi mereka untuk melindungi entitas mereka, (Allison, 2014) ddan menunjukkan kegagalan Estonia dalam setiap aspek kehidupan (Mattiisen, Grajewski, \& Supinska, 2010: 24). Alasan-alasan ini menjelaskan mengapa Rusia memiliki keinginan yang kuat untuk mempertahankan pengaruhnya dan mempengaruhi dinamika politik domestik Estonia. Dengan demikian, artikel ini akan fokus pada persepsi ancaman dan respon Estonia terhadap strategi hybrid warfare Rusia yang akan dijelaskan lebih dalam pada bagian-bagian selanjutnya.

\section{STRATEGI HYBRID WARFARE RUSIA DAN ANCAMAN BAGI ESTONIA}

Hybrid warfare merupakan strategi yang diterapkan oleh Rusia dalam meganeksasi wilayah Krimea dalam konflik Ukraina tahun 2014. Dalam penerapannya, keberhasilan penggunaan strategi ini menjadi sebuah pukulan bagi Barat akan tantangan dari penggunaan kekuatan non konvensional sebagai senjata dalam melaksanakan perang. Lingkungan strategis di era kontemporer memang memaksa aktor-aktor dalam menerapkan taktik yang dianggap paling efektif dalam mencapai kepentingannya. Saat ini dunia sedang memasuki fase Perang Generasi Keempat (4GW) di mana medan perang tidak hanya dilakukan dalam batas-batas yang ditentukan tetapi di suluruh cyberspace akibat kemajuan teknologi yang semakin modern. Kondisi lingkungan strategis tersebut yang pada akhirnya mendukung konflik di masa depan menjadi multi-modal dan multivariant (Hoffman, 2009:5). Dengan demikian, kekuatan asimetris membawa peran yang cukup signifikan sebagai salah satu indikator yang diterapkan oleh negara dalam memproyeksikan kepentingan mereka.

Melihat perkembangan lingkungan strategis yang ada pada akhirnya mendorong Rusia sebagai salah satu great power di kawasan dalam mengembangkan strategi hybrid warfare untuk mendapatkan keuntungan geopolitik. Secara terminologi, hybrid warfare sendiri didefinisikan sebagai penggabungan mode peperangan yang berbeda baik dari 
kapabilitas konvensional, taktik dan formasi yang tak beraturan, tindakan teror dan kekerasan, serta kekacauan kriminal (Hoffman, 2009). Selain itu, hybrid warfare juga dapat melibatkan aktivitas cyberspace yang ofensif; dan operasi psikologis yang menggunakan media sosial dan tradisional untuk mempengaruhi persepsi dan opini internasional (The Military Balance 2015: 17).

Persepsi Rusia tentang strategi hybrid warfare tertulis melalui sebuah artikel yang ditulis oleh Valery Gerasimov-Kepala Staff Umum Rusia_di dalam surat kabar VoennoPromyslenni Kurier pada Februari 2013, dikatakan bahwa Rusia telah mengembangkan strategi perang yang lebih modern dan disesuaikan dengan kondisi lingkungan strategis saat ini. Dalam tulisannya, Gerasimov menyatakan bahwa etika perang telah berubah begitu pula dengan sarana non militer-penggunaan secara luas tindakan politik, ekonomi, informasi, kemanusiaan, dan sarana non militer lainnya-yang dapat digunakan sebagai alat untuk pencapaian tujuan politik dan strategis yang semakin berkembang. Dengan demikian, sarana non militer tersebut dapat berperan dalam mode peperangan yang lebih efektif, bahkan melampaui kekuatan konvensional (Gerasimov, 2013).

Penggabungan taktik konvensional dan non konvensional tersebut yang pada akhirnya diterapkan oleh Rusia untuk melakukan tindakan agresif di negara-negara tetangga. Ancaman yang diproyeksikan oleh Rusia mencakup serangan siber, serangan informasi, propaganda canggih, manipulasi media, ancaman ekonomi, tindakan proxy, eksploitasi perselisihan etnis, dan mendatangkan agen yang disengaja dan tidak disengaja di negara-negara asing untuk menanamkan pengaruh mereka (Weitz, 2014). Kombinasi dari serangan tersebut justru tidak mengurangi kebahayaan yang dapat ditimbulkan, justru dapat melemahkan politik domestik negara yang menjadi target sehingga semakin mudah untuk dilakukan invasi lebih lanjut. Bagi Rusia yang menjadi rival negara Barat dan NATO, penerapan strategi ini akan membawa keuntungan yang besar karena negara Barat dan NATO masih cenderung mengimplementasikan cara-cara tradisional dalam merespon ancaman. Strategi hybrid warfare dapat menciptakan ambiguitas terhadap tindakan Rusia di masa depan dan dapat mempersulit negara lain untuk melakukan kontra strategi atas ancaman dan serangan yang sulit diprediksi. Itulah yang kemudian dimanfaatkan oleh Rusia dalam membangun kekuatan asimetris mereka untuk merespon tantangan Barat.

Penggunaan strategi hybrid warfare kemudian berimplikasi pada dinamika keamanan di kawasan, khususnya bagi negara-negara bekas Soviet, termasuk Estonia. 
Estonia merupakan negara demokratis di kawasan Soviet yang dianggap paling rentan dalam menghadapi ancaman hybrid warfare Rusia. Hal itu tidak bisa dilepaskan dari sejarah hubungan Rusia dan Estonia di masa lalu serta ancaman-ancaman yang dihadirkan oleh Rusia terhadap Estonia. Estonia memiliki pengalaman pahit dalam menghadapi serangan hybrid dari Rusia dalam peristiwa The Bronze Night yang menyebabkan kerusuhan etnis minoritas Rusia di kota Tallin (Lucas \& Pomeranze, 2016:22). Faktor historis tersebut berkorelasi pada keberadaan entitas minoritas berbahasa Rusia di Estonia juga menjadi pendorong kerentanan Estonia terhadap ancaman hybrid. Keberadaan entitas tersebut menguntungkan pihak Rusia karena mereka lebih mudah mendapatkan serangan disinformasi. Tertulis dalam Strategi Pertahanan Nasional Estonia bahwa lingkungan keamanan yang berkembang pesat saat ini juga menjadi ancaman potensial yang serius bagi Estonia. Ancaman tersebut berasal dari ancaman hybrid dan kombinasi tantangan dari perkembangan eksternal dan internal. Hal itu berimplikasi pada pertahanan Estonia yang tidak hanya fokus pada pengggunaan kekuatan konvensional tetapi seluruh otoritas negara Estonia harus berpartisipasi dalam mengembangkan kekuatan non-militer (National Defence Strategy, 2011) .

Terlepas dari penjelasan mengenai hybrid warfare Rusia dan kerentanan Estonia itu sendiri, terdapat kajian-kajian literatur yang telah ditulis oleh beberapa akademisi yang dapat dipelajari untuk memahami fenomena yang akan dikaji oleh penulis. Para akademisi mengkaji fenomena hybrid warfare dan persepsi ancaman dengan menggunakan sudut pandang dan pendekatan yang berbeda. Kajian-kajian literatur tersebut secara garis besar terbagi menjadi dua yaitu kajian strategis dan kajian kontra strategi. Dalam kajian strategis, para akademisi membahas hybrid warfare secara konseptual sebagai sebuah strategi yang diterapkan oleh Rusia untuk mencapai kepentingan politiknya. Bagi para akademisi, hybrid warfare secara garis besar merpakan strategi yang dapat mengancam Barat, khususnya NATO dan Uni Eropa (Banasik, 2016); hybrid warfare mampu menciptakan ambiguitas dari sikap Rusia yang berpengaruh pada sulitnya para pembuat keputusan dalam merespon ancaman yang ditimbulkan (Mastriano, 2017); hybrid warfare tidak mengubah sifat perang yang masih menggunakan kekerasan terorganisir untuk mendapatkan keuntungan psikologis dari lawan dan berpengaruh secara signifikan terhadap kebijakan militer Barat (Wither, 2016); hybrid warfare tetap didukung oleh kekuatan konvensional yang terus dikembangkan Rusia untuk lebih bisa memobilisasi negara (Monaghan, 2016). 
Melihat dari sifat strategi hybrid warfare itu sendiri, dibutuhkan upaya deterrence dalam meresponnya (Johnson, 2017). Sementara itu Rusia memandang bahwa penerapan strategi hybrid warfare merupakan bagian dari upaya deterrence mereka dalam kebijakan keamanan dan pertahanan Rusia (Bruusgaard, 2016). Pada akhirnya, penerapan strategi hybrid warfare dianggap sebagai perang Rusia kontemporer yang lebih dari sekedar perang tetapi penciptaan kembali seni strategis di mana alat-alat kekuasaan negara diintegrasikan ke dalam satu kesatuan tunggal (Seely, 2017). Tetapi dalam literatur kritis menilai bahwa pendekatan hybrid dalam pelaksanaan perang kontemporer di Rusia menyebabkan pemahaman miring mengenai kemampuan militer Rusia dan penggunaan hybrid warfare hanya untuk mengkonseptualisasikan perkembangan dalam militer Rusia, tetapi dalam kebijakan luar negeri negara pada umumnya, dapat menyebabkan konsekuensi yang tidak diinginkan (Renz, 2016).

Sementara itu, dalam kajian kontra strategis, para akademisi lebih fokus mengkaji megenai respon NATO dalam menghadapi ancaman yang ditimbulkan oleh strategi hybrid warfare Rusia. NATO melakukan beberapa pendekatan yaitu melalui upaya peningkatan kehadiran pasukannya di Eropa Tengah dan Timur berdasarkan Readiness Action Plan (Michael, 2015); penggunaan anggaran secara lebih efisien untuk menghasilkan lebih banyak kemampuan multinasional dan spesialisasi peran dari masing-masing negara anggota untuk mengembangkan kapabilitas mereka (Shea, 2015); menerapkan strategi deterrence dan resilience. Strategi resilience fokus pada sektor maritim dengan pembangunan infratsruktur bawah laut (Schaub Jr, Murphy, \& Hoffman, 2017). Sementara strategi deterrence fokus pada peningkatan kehadiran pasukan NATO di negara Eropa Timur dan negara-negara Baltik (Zapfe, 2017); modernisasi dan standarisasi kekuatan militer dari negara anggota di Eropa Timur dan mengembangkan dan menyebarkan generasi baru senjata nuklir substrat untuk menanggapi potensi agresi nuklir dari Rusia pada tingkat taktis (Lanoszka, 2016); NATO melaksanakan patroli udara, latihan militer gabungan, penempatan peralatan militer berat, dan penempatan empat batalyon kekuatan rotasi kecil lainnya di wilayah tersebut (Lanoszka \& Hunzeker, 2016).

Dari argumen yang dibentuk baik dari kajian strategis dan kontra strategis dapat diambil pelajaran bahwa lingkungan strategis di era kontemporer mendorong Rusia dalam mengembangkan sebuah startegi yang lebih eektif dalam melaksanakan operasi militer dengan menggabungkan kekuatan konvensional dan non konvensional. Dan penggunaan 
strategi hybrid warfare tidak dapat dipandang sebelah mata karena justru membuat dinamika konflik semakin kompleks karena dapat membawa kerusakan yang tidak kalah besar dari penggunaan kekuatan konvensional. Banyaknya elemen yang digunakan dalam mode perang ini membuat tantangan bagi negara lain-khususnya NATO sebagai rival terberat Rusia-menjadi semakin besar. Dalam kanjian kontra strategis sendiri, NATO hanya memfokuskan responnya yaitu menggunakan pendekatan tradisional dengan meningkatkan kehadiran pasukan untuk membendung ancaman yang ada. Respon yang dihadirkan oleh NATO menunjukkan bahwa startegi hybrid warfare memang merupakan ancaman yang nyata dan membutuhkan kontra strategi dalam mengantisipasinya. Dengan demikian, strategi hybrid warfare telah berimplikasi terhadap persepsi ancaman NATO sebagai sebuah institusi penyedia keamanan di Eropa.

Paparan kajian literatur di atas meskipun kita dapat menarik pelajaran, tetapi terdapat beberapa kekosongan literatur yang menjelaskan mengenai persepsi ancaman dari sudut pandang negara yang memiliki kerentanan secara langsung terhadap ancaman hybrid. Objek kajian yang di bahas oleh para akademisi masih terbatas pada NATO dan Rusia sebagai dua kekuatan besar yang memiliki rivalitas. Dengan kekurangan yang masih ada dalam kajian literatur, penulis ingin menekankan tulisan ini dengan mengkaji lebih dalam mengenai pembentukan persepsi ancaman itu sendiri. Penulis ingin mengetahui faktor-faktor yang mempengaruhi negara dalam mempersepsikan ancaman mereka dengan menganalisa isyarat-isyarat ancaman yang dihadirkan oleh lawan.

Estonia merupakan negara yang memiliki kerentanan besar dalam menghadapi ancaman hybrid Rusia. Melihat dari faktor historis, pengalaman ancaman di masa lalu, geopolitik, serta respon yang dihadirkan oleh Estonia menjadi penting dalam menganalisa persepsi Estonia terhadap ancaman hybrid. Dasar tersebut mengantarkan penulis pada pertanyaan penelitian yaitu bagaimana persepsi ancaman Estonia terhadap strategi hybrid warfare Rusia? Dan untuk mendapatkan jawaban atas pertanyaan tersebut, pertama-tama akan dijelaskan mengenai teori Threat Perception yang dikemukakan oleh Raymond Cohen sebagai dasar dalam menganalisa persepsi ancaman Estonia. Kedua, akan dijelaskan mengenai isyarat ancaman yang menjadi salah satu faktor pembentuk persepsi ancaman Estonia yang di uraikan melalui faktor historis dan momentum serangan hybrid ke Estonia, dan pandangan pengamat kontemporer. Ketiga, akan dijelaskan mengenai respon Estonia terhadap ancaman hybrid warfare sebagai implementasi dari persepsi ancaman mereka. 


\section{KERANGKA ANALISIS \\ THREAT PERCEPTION DALAM PEMIKIRAN RAYMOND COHEN}

Ancaman dalam studi hubungan internasional merupakan elemen yang penting dalam melihat bagaimana interaksi para aktor dalam sistem internasional yang konfliktual. Raymond Cohen merupakan salah satu akademisi yang menggagas pemikirannya mengenai persepsi ancaman dalam krisis internasional. Ancaman sendiri didefinisikan sebagai “a perception of danger" (Cohen, 1979:4). Berangkat dari definisi tersebut, Cohen menganalisa persepsi ancaman dengan melihat kebahayaan-kebahayaan yang dapat ditimbulkan oleh musuh potensial yang dapat dianalisa oleh suatu aktor dengan melihat isyarat ancaman yang ada. Sejalan dengan pengertian yang di kemukakan Cohen, ancaman juga dapat dipahami sebagai sesuatu yang berpotensi membahayakan kepentingan nasional (Robinson, 2008:212), kapabilitas, kemampuan, dan niat yang dimiliki oleh suatu kelompok untuk menimbulkan situasi dan konsekuensi negatif kepada kelompok lainnya (Davis, 2000). Tetapi tulisan ini akan fokus dalam pengertian ancaman yang dikemukakan oleh Cohen.

Definisi yang dikemukakan oleh Cohen mengenai persepsi ancaman adalah variabel intervensi yang menentukan antara aksi dan reaksi dalam krisis internasional. Jadi, para aktor tidak akan memobilisasi sumber daya defensif ketika tidak ada ancaman yang dirasakan meskipun terdapat bukti secara obyektif. Sebaliknya, ketika ancaman dirasakan maka aktor yang terancam dapat melakukan tindakan balasan meskipun sesungguhnya lawan tidak memiliki niat jahat. (Cohen, 1978:93). Dengan demikian, ancaman dipandang dalam arti pasif sebagai sebuah upaya antisipasi terhadap bahaya yang bisa muncul di masa depan daripada diartikans ecara aktif di mana mereka dapat menjatuhkan sanksi kepada lawan (Cohen, 1978:95).

Menurut Cohen, kecenderungan para pembuat keputusan dalam merasakan ancaman yang ada berasal dari keyakinan mereka terhadap isyarat ancaman (the threatening cue) yang akhirnya mendorong justifikasi terhadap apa yang dianggap sebagai suatu kebahayaan. Untuk itu, ada beberapa indikator yang dapat digunakan dalam melihat faktor apa saja yang mempengaruhi ancaman persepsi ancaman para pembuat keputusan. Pertama, artikulasi atau penilaian dari pembuat keputusan terhadap isyarat ancaman yang didasari oleh faktor historis. Faktor historis dapat dianalisa berdasarkan sejarah hubungan dari aktor-aktor yang merasa terancam maupun yang menjadi sumber ancaman. Interaksi para aktor di masa lalu yang kemudian mendorong kekhawatiran dan rasa tidak percaya 
terhadap lawan yang dianggap berpotensi membahayakan mereka. Selain itu, ketika lawan pernah memproyeksikan ancaman yang sama maka akan mendorong lawan untuk melakukan serangan yang sama di masa depan (Cohen, 1978:95). Dengan demikian, pengalaman ancaman di masa lalu juga berpengaruh terhadap persepsi ancaman. Kedua, deskripsi oleh pengamat kontemporer (diplomat luar negeri, pengamat, dan lainnya.) dari keadaan pikiran para pembuat keputusan. Ketiga adalah bukti dari eksplorasi oleh pembuat keputusan terhadap respon alternatif kepada ancaman yang dirasakan yang mencakup konsultasi internal yang intensif, peningkatan aliran infromasi, dan mencari dukungan eksternal. Keempat, respon dari pembuat keputusan terhadap ancaman yang mencakup penguatan dan mobilisasi sumber daya, perhitungan diplomatik, kebijakan, dll) (Cohen, 1978:95).

\section{METODE PENELITIAN}

Dari uraian di atas dapat disimpulkan bahwa kebahayaan dapat dilihat dari isyarat ancaman yang kemudian dipersepsikan oleh pembuat keputusan. Ketika mereka melakukan observasi terhadap isyarat ancaman dan mendapatkan bukti penilaian bahwa lawan memang memproyeksikan ancamannya, maka pambuat keputusan melakukan upaya antisipasi dengan merespon ancaman tersebut melalui kebijakan yang dikeluarkan. Berdasarkan pemikiran Threat Perception yang dikemukakan oleh Cohen, maka dapat dianalisa kondisi-kondisi yang dapat mempengaruhi persepsi ancaman Estonia dalam menilai ancaman hybrid warfare yang dikembangkan oleh Rusia. Penilaian terhadap persepsi ancaman tersebut yang akhirnya mendorong Estonia dalam merespon ancaman yang ada melalui kebijakan mereka.

\section{PEMBAHASAN}

\section{FAKTOR HISTORIS SEBAGAI ISYARAT ANCAMAN}

Estonia dan Rusia memiliki hubungan sejarah masa lalu yang panjang. Hubungan tersebut tidak bisa dilepaskan dari warisan dominasi kekaisaran Rusia dan pendudukan Soviet. Estonia merupakan wilayah yang mengalami pendudukan asing selama berabadabad oleh Denmark, Jerman, Swedia, dan Polandia, sebelum menjadi bagian dari Kekaisaran Rusia pada tahun 1721. Berakhirnya Perang Dunia I dan peristiwa Revolusi Bolshevik telah menjadikan Estonia sebagai negara yang merdeka pada tahun 1920. Kemudian Perang Dunia II, Stalin melakukan okupasi ke negara-negara Baltik termasuk Estonia yang akhirnya kembali menjadi bagian Uni Soviet pada tahun 1941 berdasarkan 
Pakta Molotov-Ribbentrop 1939 (Zunes, 2009). Tetapi pendudukan Uni Soviet di Estonia tidak diakui secara de jure oleh sebagian besar negara-negara Barat.

Pada saat Perang Dunia II, Stalin menetapkan kebijakan Russification di mana terjadi penindasan budaya Estonia dan mendorong imigrasi Rusia lebih lanjut sehingga 40\% total penduduk Estonia merupakan entitas Rusia (Zunes, 2009). Selama masa pendudukan Soviet, Estonia tetap mempertahankan tradisi mereka karena pada dasarnya mereka menganggap diri mereka sebagai negara Nordik dan Baltik. Setelah Uni Soviet runtuh pada 1991, Estonia mendapat kemerdekaannya kembali bukan sebagai sebuah negara baru melainkan atas dasar periode kemerdekaan sebelumnya. Estonia kemudian diterima sebagai anggota NATO dan Uni Eropa pada tahun 2004 dan berpengaruh pada kebijakan Estonia yang lebih berorientasi Barat (Mattiisen, Grajewski, \& Supinska, 2010).

Kemerdekaan Estonia dan masuknya Estonia sebagai anggota NATO dan Uni Eropa lantas tidak menyurutkan tensi yang terjadi dalam dinamika hubungan EstoniaRussia. Pendudukan atas Estonia dalam jangka waktu yang lama masih mempengaruhi sikap Rusia yang sulit untuk mengakui negara bekas Soviet sebagai negara berdaulat. Selain itu, perbedaan persepsi mengenai kemerdekaan Estonia menciptakan gap di antara kedua negara. Estonia menganggap bahwa kemerdekaan mereka merupakan kelanjutan kemerdekaan yang telah diperoleh dari masa Kekaisaran Rusia. Sementara Rusia menganggap Estonia sebagai sebuah negara baru setelah lepas dari Uni Soviet. Hal itu akhirnya berdampak pada hubungan Estonia-Rusia, di mana Estonia selalu menganggap Rusia sebagai ancaman yang kapan saja berpotensi untuk mengokupasi wilayah bekas Soviet demi mencapai tujuan politik mereka.

Narasi sejarah juga berpengaruh terhadap demografi di Estonia yang memiliki entitas minoritas berbahasa Rusia. Tercatat dalam data bahwa tahun 2011 total 31\% penduduk Estonia bukan merupakan etnis Estonia asli di mana 25,5\% dari total penduduk mewakili etnis Rusia (Statistics Estonia 2011:56). Saat pendudukan Uni Soviet, Rusia menuduh Estonia mempraktekkan kebijakan mono-etnik dengan standar ganda, diskriminasi, serta pembersihan etnis selain etnis asli Estonia melalui Estonisasi. Estonisasi merupakan sebuah istilah yang digunakan oleh beberapa politisi Rusia dalam menggambarkan kebijakan penindasan hak-hak orang Rusia di Estonia saat periode Soviet (V.N. Yelagin, 1994:66). Estonisasi itulah yang kemudian dijadikan narasi oleh Rusia pasca kemerdekaan Estonia dalam membentuk citra Rusia dalam entitas minoritas 
berbahasa Rusia di Estonia. Rusia menyebarka kisah-kisah bahwa Estonia masih merupakan bagian dari Rusia dan memiliki keterikatan budaya dan sejarah. Sementara itu setelah kemerdekaannya, Estonia berupaya untuk menerapkan kebijakan yang dirancang untuk meminimalkan pengaruh Rusia terhadap budaya Estonia (Herzog, 2011). Kebijakan tersebut dianggap Rusia sebagai salah satu cara Estonia dalam mendiskriminasi entitas berbahasa Rusia dan menghilangkan budaya Rusia di Estonia (Mattiisen, Grajewski, \& Supinska, 2010).

Uraian di atas yang kemudian memiliki korelasi terhadap upaya-upaya Rusia dalam menyebarkan retorika mengenai diskriminasi entitas berbahasa Rusia yang ada di Estonia. Rusia dapat melakukan legal rhetoric sebagai upaya justifikasi atas tindakan agresifnya dan memanfaatkan ketidakpastian dalam hukum internasional dalam membuat pembenaran atas intervensinya. Pembenaran itu antara lain, Rusia meng-klaim ingin melindungi masyarakatnya — entitas berbahasa Rusia—dari diskriminasi yang dilakukan oleh negara lain (Allison, 2014). Melalui media dan informasi, Rusia menggunakan entitas tersebut sebagai mesin propaganda. Di wilayah dengan mayoritas entitas berbahasa Rusia sendiri merupakan ruang informasi yang dikuasai oleh Rusia. Masyarakat tidak menggunakan bahasa Estonia, menonton saluran TV Rusia (Rossiya/RTR, NTV, REN TV, PBKsaluran Baltik pertama yang menyiarkan kembali program-program Rusia) (Dougherty \& Kaljurand, 2015), mendengarkan radio Rusia, serta membaca surat kabar Rusia. Penggunaan strategi hybrid warfare dalam aneksasi Krimea-di mana media dan informasi memegang peran utama dalam menentukan keberhasilan peperangan-menjadikan Estonia semakin waspada terhadap ancaman yang ditimbulkan Rusia.

Penyebaran berita-berita mengenai diskriminasi entitas berbahasa Rusia dan narasi anti-NATO dalam ruang informasi yang ada di Estonia dianggap sebagai sebuah isyarat ancaman sesuai dengan yang dinyatakan Cohen dalam asumsinya mengenai Threat Perception. Para pembuat keputusan di Estonia mengobservasi melalui peristiwa dan tanda-tanda yang menjadi fokus dari kebijakan pemerintah Estonia terhadap fenomena yang menjadi perhatian. Pejabat pemerintah Estonia, didukung dengan pengamat kebijakan luar negeri Barat, telah memperingatkan mengenai bahaya penetrasi media Rusia. Ketika serangan informasi sudah digunakan pada entitas berbahasa Rusia, maka akan menyebabkan ketegangan sosial dan memicu provokasi seperti yang terjadi di Ukraina (Dougherty \& Kaljurand, 2015:4). Kebahayaan akan isyarat ancaman tersebut ditegaskan 
oleh ketua Komite Pertahanan Nasional Parlemen Estonia, Marko Mihkelson, yang menyatakan:

"The level of sophistication of their use of media, both in TV and social media, the Internet, whatever, is on the highest level. There is the potential to generate some sort of anti-government action in Estonia, if it is needed (Marko Mihkelson, 2015).

Dari pernyataan tersebut mengisyaratkan potensi ancaman dari Rusia untuk mempengaruhi entitas berbahasa Rusia. Hal itu menjadi mudah bagi Rusia karena entitas berbahasa Rusia tersebut kurang terintegrasi dengan Estonia secara lebih dalam. Mereka memang menjadi warga negara Estonia dan menjadikan Estonia sebagai rumah mereka, tetapi mereka tidak memiliki hubungan yang erat dengan Estonia. Tomas Jermalavičius, seorang ahli pertahanan di Estonia, menyatakan:

"The perceptions are there, the fears and anxieties are there, the lack of trust is there (Tomas Jermalavičius, 2015)."

Pernyataan tersebut menyimpulkan bahwa terdapat persepsi ancaman, rasa takut, kekhawatiran, dan ketidakpercayaan terhadap Rusia. Dengan spektrum hybrid warfare yang luas dan tidak hanya mengandalkan kekuatan konvensional, membuat serangan dapat dilakukan kapan saja. Terlebih Rusia telah memiliki akses dalam menguasai ruang informasi bagi entitas berbahasa Rusia di Estonia sehingga semakin mudah bagi mereka untuk menyebarkan propaganda-propaganda untuk mengganggu politik domestik di Estonia. Entitas berbahasa Rusia memiliki perspektif mereka sendiri mengenai Estonia di mana mereka juga tidak percaya kepada pemerintah karena faktor sejarah, lingkungan ancaman dan kebijakan nasional Estonia. Ketika mereka mendapatkan tekanan dalam perkembangan keamanan maka mereka cenderung untuk mendukung kutub yang berlawanan, terutama ketika Rusia terlibat di dalamnya (Dougherty \& Kaljurand, 2015). Dengan demikian, faktor sejarah hubungan Estonia-Rusia memegang peran penting dalam mempengaruhi persepsi ancaman Estonia. Kepahitan Estonia di masa pendudukan Soviet telah meningkatkan rasa tidak percaya atas tindakan Rusia, terlebih yang dianggap sebagai sebuah isyarat ancaman.

\section{PENGALAMAN ANCAMAN DI MASA LALU SEBAGAI ISYARAT ANCAMAN}

Hubungan Estonia-Rusia yang memiliki sejarah panjang dalam menciptakan rasa tidak percaya serta kekhawatiran terhadap ancaman yang dapat diproyeksikan oleh Rusia 
juga didukung oleh momentum serangan hybrid Rusia ke Estonia di masa lalu. Pengalaman-pengalaman akan ancaman Rusia tersebut meningkatkan kerentanan Estonia terhadap ancaman hybrid. Berkolerasi dengan entitas berbahasa Rusia yang dapat dijadikan mesin propaganda oleh Rusia, maka serangan disinformasi tersebut pernah dilakukan Rusia pada peristiwa the Bronze Night tahun 2007. Peristiwa tersebut merupakan peristiwa kerusuhan di Tallin oleh gerakan pemuda pro-Rusia akibat kebijakan pemerintah Estonia untuk merelokasi monumen The Bronze Soldier untuk mengenang tentara-tentara Soviet yang gugur pada Perang Dunia II (Lucas \& Pomeranze, 2016).

Keberadaan entitas berbahasa Rusia di Estonia memang dapat menjadi bumerang bagi pemerintah Estonia jika mereka tidak dapat melakukan pendekatan-pendekatan sebagai upaya untuk lebih mengintegrasikan mereka terhadap budaya dan nasionalisme di Estonia itu sendiri. Dengan perbedaan entitas yang sangat besar, mereka mudah untuk dijadikan sebagai mesin propaganda pemerintah negara lain—khususnya Rusia — untuk mencapai tujuan strategis dan geopolitik. Peristiwa the Bronze Night diyakini oleh Urmas Paet-Menteri Luar Negeri Estonia — sebagai akibat dari serangan disinformasi Rusia (Herzog, 2011:51). Upaya disinformasi tersebut dilakukan dengan cara menghasut entitas berbahasa Rusia dengan menggunakan media yang menyebarkan berita bahwa monumen telah dihancurkan. Kedutaan Besar Rusia juga bertanggung jawab dalam melakukan upaya penghasutan pada entitas berbahasa Rusia dan memanfaatkan ledakan emosi mereka untuk melakukan tindak kekerasan seperti konfrontasi dengan polisi dan penjarahan (Praks, 2015:5).

Ketegangan hubungan kedua negara semakin memuncak saat Rusia juga dianggap sebagai aktor yang melakukan serangan siber melalui DDoS. Yang menjadi target serangan siber adalah infrastruktur negara Estonia dengan cara menutup situs web semua kementerian pemerintah, dua bank besar, dan beberapa partai politik, selain itu para peretas juga menonaktifkan server email parlementer Estonia (Ruus, 2008). Dari peristwa di atas dapat dianalisa bahwa ancaman secara langsung telah diproyeksikan oleh Rusia di Estonia. Entitas berbahasa Rusia memang berperan penting dalam meningkatkan kerentanan Estonia terhadap ancaman hybrid. Hal itu yang akhirnya dimanfaatkan oleh Rusia dalam melihat kondisi lingkungan strategis di Estonia.

Narva, salah satu kota di Estonia menjadi sorotan dalam hal ini karena didominasi oleh entitas berbahasa Rusia. Narva merupakan kota dengan entitas berbahasa Rusia yang paling banyak. Dan dengan dominasi entitas tersebut, mereka masih memiliki masalah 
dengan kewarganegaraan. Data statistik menunjukkan bahwa di Narva terdapat $46 \%$ penduduk campuran Estonia, 37\% warga negara Rusia, dan penduduk tanpa kewarganegaraan 10\% (Statistik Estonia, 2011). Sementara mereka termarjinalkan oleh pemerintah Estonia sendiri dan cenderung tidak memiliki keterlibatan politik bahkan partisipasi dalam pemilu di Estonia (Trimbach \& O’Lear, 015). Kemudian, dilihat secara geopolitik, Narva memiliki jarak kedekatan geografis dengan Rusia di mana kota ini pernah menjadi bagian dari kota St. Petersburg ketika masih menjadi bagian dari Uni Soviet. Dengan demikian, Narva memiliki nilai strategis bagi Rusia baik secara kedekatan historis dan geopolitik sehingga memudahkan Rusia dalam memproyeksikan strategi hybrid warfare mereka. Dalam hal ini, faktor geopolitik di Narva juga memiliki peran dalam meningkatkan Rusia dan NATO.

Serangan-serangan Rusia yang memanfaatkan kerentanan masalah etnisitas dan kelemahan Estonia dalam mengintegrasikan entitas berbahasa Rusia tersebut merupakan isyarat ancaman yang nyata yang juga mempengaruhi hubungan Estonia-Rusia. Peristiwa the Bronze Night menunjukkan bahwa Rusia secara sadar merehabilitasi simbol Soviet dan menanamkan sejarah versi Soviet dalam entitas berbahasa Rusia di Estonia. Dengan demikian, hubungan Estonia-Rusia akan tetap berada dalam ketegangan ketika narasi sejarah masih memainkan peran yang besar dalam pergolakan entitas yang ada di dalamnya. Bagaimana pun ketika melihat pada kepentingan kedua negara, mereka seperti memiliki dua versi sejarah yang berbeda. Jadi narasi sejarah dalam hal ini juga berkorelasi dengan serangan hybrid Rusia dalam peristiwa The Bronze Night. Seperti yang sudah dijelaskan sebelumnya bahwa narasi sejarah tersebut yang akhirnya akan menciptakan rasa tidak percaya dan kekhawatiran akan ancaman Rusia di masa depan. Hal itu telah dibuktikan oleh Rusia dengan melakukan serangan yang difokuskan pada penggunaan kekuatan non konvensional dalam melemahkan pemerintah domestik Estonia dengan memanfaatkan narasi identitas.

Otoritas Keamanan Infomasi Estonia (Estonian Information Security Authority) melaporkan bahwa terjadi peningkatan yang cukup besar dalam tingkat keparahan serangan dan ancaman siber di tahun 2014-2016. Setidaknya terdapat 1.151 insiden di tahun 2014 di mana serangan tersebut ditujukan untuk merusak layanan dan reputasi negara dan meningkat tahun 2015 di mana terdapat 5809 kasus serangan siber (2015 Annual Report: Cyber Security Branch Of the Estonian Information System Authority). 
Sementara itu di tahun 2016 terdapat 9.135 kasus di jaringan komunikasi data dan komputer Estonia di mana 2.248 di antaranya merupakan insiden keamanan cyber berdasarkan laporan Tim Tanggap Darurat Komputer Estonia (CERT-EE) (2017 Annual Report: Cyber Security Branch Of the Estonian Information System Authority). Sementara di tahun 2016 kembali terjadi insiden disinformasi terjadi saat sebuah stasiun televisi Rusia Vesti-Rossiya 24 menayangkan sebuah demonstrasi kemenangan besar di entitas berbahasa Rusia di kota Sillamäe. Dalam tayangan itu menggambarkan orang-orang Estonia sebagai pendukung Nazi dan Holocaust, sementara pada saat yang sama penonton diingatkan pada perjuangan heroik mereka melawan kelompok pembebasan Rusia setempat (Lucas \& Pomeranzev, 2016:21).

Ancaman tidak hanya berasal dari ancaman siber dan disinformasi tetapi juga ancaman militer yang dirasakan Estonia pada tahun 2014 ketika Rusia meningkatkan kekuatan militernya di daerah perbatasan negara-negara tetangga yang meliputi wilayah udara dan zona maritim. Peningkatan kapabilitas militer dilakukan dengan pengembangan kemampuan penolakan anti-akses/area baru, sistem pengawasan dan pengintaian baru, rudal canggih dan rudal balistik taktis (Smith \& Hendrix, 2016:7). Rusia juga melakukan latihan militer yang ekstensif dan diselenggarakan di perbatasan-perbatasan negara Baltik. Di tahun 2009 Rusia mengadakan dua latihan militer besar yang mensimulasikan pendudukan negara-negara Baltik dan pagelaran dan penggunaan senjata nuklir di mana salah satu targetnya adalah Warsawa. Sementara di tahun 2013, latihan besar ditujukan untuk meningkatkan kemampuan mobilisasi pasukan dan peralatan tempur dalam jumlah besar (Lucas, 2015). Tindakan agresif berikutnya adalah terjadinya pelanggaranpelanggaran di wilayah udara Estonia oleh pesawat Rusia sebanyak tujuh insiden di mana pesawat tempur Rusia secara teratur menyusup atau mendekati wilayah udara negara Baltik (Tambur, 2014). Penggunaan kekuatan militer Rusia di Estonia sendiri bisa berupa serangan terbatas dalam bentuk ruang, waktu, dan kekuatan hingga operasi besar yang bertujuan untuk menaklukkan Estonia (Praks, 2015:7). Provokasi juga pernah terjadi di perbatasan Estonia pada September 2014 di mana petugas keamanan Estonia ditangkap saat sedang melakukan investigasi yang akhirnya mendorong Presiden Obama untuk melakukan kunjungan ke Tallin dan menegaskan jaminan keamanan Amerika (Jakniunaite, 2016).

Dari uraian di atas dapat dilihat bahwa selain ancaman disinformasi dan cyber, Rusia juga meningkatkan ancaman militernya. Dalam upaya memproyeksikan serangan hybrid, 
penggunaan kekuatan konvensional masih memiliki peran yang besar meskipun kekuatan tersebut tidak diproyeksikan secara langsung. Tetapi dengan peningkatan kapabilitas militer dan tindakan agresif di wilayah perbatasan, menunjukkan bahwa Rusia memang memiliki intensi dalam melakukan serangan di masa depan terhadap negara-negara Baltik. Hal ini jelas menjadi sebuah isyarat ancaman bagi Estonia karena Estonia dianggap negara Baltik yang paling rentan terhadap serangan hybrid Rusia. Meskipun terdapat kemungkinan kecil dalam serangan langsung Rusia ke Estonia, tetapi bagaimana pun isyarat ancaman telah diterima dan Rusia dianggap sebagai ancaman terbesar.

"The use of military power against the Baltic States cannot be entirely ruled out since conflicts that occur farther away may spill over into the Baltics" (Estonian Information Board, 2016: 9).

Dari pernyataan tersebut, secara geopolitik, ancaman militer yang diproyeksikan oleh Rusia di negara-negara Baltik tidak dapat diremehkan oleh pemerintah Estonia. Peristiwaperistiwa tersebut merupakan bagian dari isyarat ancaman yang dirasakan oleh Estonia. Isyarat ancaman tersebut berpengaruh terhadap dinamika keamanan di kawasan yang tidak stabil. Bagaimana pun, Rusia merupakan sumber ancaman eksternal dan eksistensial yang dianggap paling mengkhawatirkan di kawasan dibandingkan ancaman lainnya seperti masalah terorisme atau migrasi. Keberhasilan setiap serangan yang dilakukan oleh Rusia secara otomatis berimplikasi pada peningkatan rasa khawatir dan tidak percaya akan setiap tindakan yang diambil oleh Rusia. Agresi Rusia dianggap sangat mungkin ketika Estonia percaya bahwa ancaman dilakukan oleh Rusia secara terus-menerus dan menuntut Estonia untuk beradaptasi dengan destabilisasi yang diciptakan oleh Rusia. Dari analisa tersebut dapat dikatakan bahwa penggunaan kekeuatan non konvensional oleh Rusia dalam setiap tindakan agresif yang dilakukan juga menimbulkan efek kebahayaan yang besar bagi Estonia. Rusia sedapat mungkin mengurangi penggunaan kekerasan dalam setiap tidakan agresif di Estonia, tetapi justru penggunaan kekuatan non konvensional juga dapat menyebabkan kehancuran yang besar secara internal bagi negara target, dalam hal ini adalah Estonia.

\section{PANDANGAN PENGAMAT KONTEMPORER DALAM MELIHAT ISYARAT ANCAMAN}

Salah satu asumsi dalam teori Threat Perception yang dikemukakan oleh Cohen adalah pandangan para pengamat kontemporer dalam melihat fenomena yang menjadi 
fokus kajian. Pandangan tersebut membawa pengaruh kepada pemikiran pembuat keputusan dalam melakukan observasi terhadap isyarat ancaman yang ada (Cohen, 1978). Dari penjelasan di bagian sebelumnya telah diketahui bahwa faktor historis dan pengalaman terhadap ancaman di masa lalu merupakan sebuah artikulasi dari isyarat ancaman yang telah diobservasi oleh pembuat keputusan. Hal itu didukung dengan bagaimana pengamat kontemporer melihat isyarat ancaman yang ada. Pengamat kontemporer dalam hal ini adalah para diplomat, pengamat keamanan, atau aktor-aktor lainnya yang juga mengemukakan pendapat mereka mengenai fenomena yang terjadi. Seorang mantan diplomat Estonia di Amerika (2011-2014) dan mantan Menteri Luar Negeri Estonia (2015-2016), Marina Kaljurand, menyatakan pandangannya mengenai tantangan dan ancaman yang dihadapi oleh Estonia. Kaljurand menyatakan:

"2007 was the low point of our bilateral relations.... It was clear the physical attacks were a red line for the Russian people. They would stop me in the street to express their support and sympathy. Many said they did not agree with the policies of the Estonian government, but this was not the way to treat diplomats." (Maria Kaljurand dalam Bussines Ukraine Magazine, 2016)

Pernyataan ini memberi kesan bahwa Rusia memang melakukan tindakan egresif terhadap Estonia sejak tahun 2007 dan hal itu mempengaruhi hubungan Estonia-Rusia hingga saat ini. Serangan yang dilakukan oleh Rusia ke Estonia dapat berpengaruh dalam politik domestik di Estonia karena dapat memicu kudeta atau penggulingan terhadap pemerintah yang sedang berkuasa. Hal itu yang juga mendorong Estonia lebih dekat terhadap Barat meskipun Kaljurand sendiri melayangkan kritiknya terhadap Barat dan menyatakan bahwa Barat masih gagal dalam mengadopsi sikap yang lebih keras terhadap Rusia sejak tahun 2000-an (Bussines Ukraine Magazine, 2016). Pandangan pengamat kontemporer lainnya datang dari mantan Sekretaris Jenderal NATO (2009-2014), Andres Fogh Ramussen, yang menyatakan pendapatnya mengenai ancaman Rusia khususnya ancaman siber dan disinformasi yang menjadi tantangan bagi negara Eropa sejak awal abad-21. Dalam pernyataannya dalam sebuah wawancara di the Telegraph, Ramussen mengatakan:

"This is not about Ukraine. Putin wants to restore Russia to its former position as a great power. There is a high probability that he will intervene in the Baltics to test Nato's Article 5." (Andres Fogh Ramussen, The Telegraph, 2015) 
Ramussen juga menambahkan bahwa Rusia dapat menerapkan serangan hybrid terhadap negara-negara Baltik, khususnya di Estonia dan Latvia, di mana terdapat banyak minoritas berbahasa Rusia (The Telegraph, 2015). Hal itu menunjukkan bahwa ada resiko besar yang dihadirkan oleh Rusia di kawasan yang harus menjadi perhatian bagi NATO sebagai penyedia keamanan untuk konsisten terhadap collective defense mereka, termasuk jaminan keamanan bagi Estonia yang sangat rentan terhadap ancaman hybrid. Rusia dapat menggunakan dalih perlindungan terhadap entitas berbahasa Rusia yang ada di Estonia untuk menjustifikasi setiap tindakan dan serangan yang dilakukan. Dan hal ini yang akhirnya menjadi perhatian bagi pengamat kontemporer terhadap situasi keamanan di Estonia dalam menghadapi tantangan yang dihadirkan oleh strategi hybrid warfare Rusia.

Pandangan pengamat kontemporer tersebut menjadi penting bagi para pembuat keputusan di Estonia dalam menentukan kebijakan mereka dalam menghadapi ancaman yang ada. Hal itu ditunjukkan dengan tanggapan dari Perdana Menteri Estonia Taavi Rõivas atas pernyataan Ramussen yang melihat bahwa tindakan asertif Rusia dapat membuka front perang hybrid baru di Estonia. Dalam tanggapannya Rõivas menyatakan bahwa Estonia telah mempertimbangkan skenario terburuk dan mempersiapkan pertahanan untuk menghadapi ancaman hybrid. Rõivas menyatakan:

"It is clear that the government must continue to build up Estonia's defenses. Only by investing in security and increase the presence of allies can we deter any potential aggressor. If we are serious enough about our own security, then foreign enemies do not threaten us (Taavi Rõivas dalam ERR News, 2015)"

Dari pernyatan di atas dapat dianalisis bahwa pandangan pengamat kontemporer menjadi penting ketika itu juga membawa pengaruh bagi para pembuat keputusan di Estonia dalam melihat tantangan yang ada. Dalam hal ini pengamat kontemporer juga melihat isyarat ancaman yang sama dengan pembuat keputusan di Estonia sehingga setelah mengobservasi bahwa tindakan agresif Rusia merupakan ancaman yang nyata, mereka berada di tahap penilaian (appraisal) bahwa ancaman yang ada membutuhkan respon dan kebijakan dalam upaya antisipasinya. Hal ini sesuai dengan teori Threat Perception yang dikemukakan oleh Cohen bahwa persepsi ancaman merupakan upaya antisipasi terhadap kebahayaan yang dirasakan (Cohen, 1978). Pada akhirnya, upaya antisipasi tersebut diimplementasikan melalui respon terhadap ancaman strategi hybrid warfare Rusia oleh 
para pembuat keputusan di Estonia yang akan dijelaskan lebih lanjut pada bagian selanjutnya.

\section{RESPON ESTONIA TERHADAP STRATEGI HYBRID WARFARE RUSIA}

Isyarat-isyarat ancaman yang merupakan sebuah hasil artikulasi dan observasi dari para pembuat keputusan terhadap ancaman hybrid Rusia pada akhirnya mendorong respon dari pemerintah Estonia dalam menghadapi tantangan yang ada. Respon tersebut diimplementasikan berdasarkan bukti dari eksplorasi para pembuat keputusan terhadap respon alternatif yang dapat dilakukan. Dukungan eksternal merupakan salah satu bentuk bukti eksplorasi terhadap ancaman yang dihadapi oleh Estonia. Dalam hal ini, dukungan eksternal Estonia secara khusus diperoleh dari NATO sebagai bagian dari jaminan aliansi mereka. Dokumen Strategi Pertahanan Estonia menuliskan bahwa kebijakan pertahanan Estonia didasarkan pada dua pilar yang saling terkait yaitu promosi keamanan internasional yang di dalamnya mencakup hubungan yang kuat dengan sekutunya serta kredibilitas mekanisme pertahanan kolektif NATO. Pilar kedua adalah peningkatan kemampuan pertahanan Estonia sendiri untuk menjamin keberlanjutan negara dan lembaga dalam semua skenario yang mungkin terjadi (National Defence Strategy Estonia, 2011).

NATO sendiri dalam hal ini juga memiliki kewajiban yang tertulis dalam Pasal 5 mengenai pertahanan kolektif yang menyatakan bahwa serangan bersenjata terhadap satu atau lebih dari negara anggota aliansi akan dianggap sebagai serangan terhadap seluruh anggota aliansi (The North Atlantic Treaty, 1949). Dengan demikian NATO bertekad untuk menjamin keamanan di negara-negara Baltik terkait dengan ancaman hybrid. Komitmen ini ditegaskan kembali oleh Obama yang saat itu menjabat sebagai Presiden Amerika saat mengunjungi Estonia di Tallin pada 3 September 2014. Dalam keterangannya, Obama menyatakan:

"We will defend our NATO Allies, and that means every Ally. . . And we will defend the territorial integrity of every single Ally. . . Because the defense of Tallinn and Riga and Vilnius is just as important as the defense of Berlin and Paris and London. . . . Article 5 is crystal clear: An attack on one is an attack on all. . . We'll be here for Estonia. We will be here for Latvia. We will be here for Lithuania. You lost your independence once before. With NATO, you will never lose it again" (Remarks by President Obama to the People of Estonia, 2014) 
Dalam pernyataannya secara jelas menegaskan dukungan NATO untuk negaranegara Baltik dalam menjamin keamanan mereka. Meskipun selama ini jaminan keamanan NATO hanya fokus pada isu-isu keamanan tradisional, tetapi NATO tidak menutup dukungan dalam membantu negara-negara anggota dalam menghadapi tantangan dari ancaman hybrid karena ancaman hybrid yang diproyeksikan oleh Rusia juga merupakan ancaman bagi NATO. Peran NATO dapat dilihat dalam membangun kesadaran situasional untuk memahami tantangan yang ada dan mengidentifikasi taktik hybrid yang diterapkan oleh Rusia (Praks, 2015:10). Peristiwa aneksasi Krimea telah menjadi pukulan besar dari Barat sehingga mendorong NATO untuk memperkuat pertahanan pada aliansi sayap Timur yang didasarkan dengan NATO's 2014 Wales summit. Peningkatan pertahanan tersebut dilakukan melalui upaya deterrence NATO untuk meningkatkan kehadirannya di negaranegara Eropa Timur, termasuk memberikan bantuan militer dan intelijen dan kemampuan peringatan dini, memperkuat keamanan cyber, kekuatan udara, dan patroli perbatasan dan kontra pemberontakan. Selain itu, etnis minoritas juga harus dimasukkan ke dalam konsep identitas nasional bersama karena etnis minoritas justru dapat menjadi sumber dari kerentanan negara-negara tersebut (Lanoszka, 2016:191).

Peningkatan komitmen NATO terhadap upaya collective defense kembali ditegaskan dalam 2016 Warsaw Summit yang menetapkan pasukan NATO akan ditingkatkan di wilayah Estonia, Latvia, Lithuania dan Polandia. Hal itu diimplementasikan sepenuhnya pada Juni 2017 dengan menghadirkan pasukan multinasional sejumlah empat batalyon kelompok tempur yang beroperasi bersama dengan pasukan pertahanan nasional dari setiap negara, termasuk di dalamnya Estonia (NATO, 2018). Dukungan eksternal yang diperoleh dari NATO menjadi sangat penting bagi Estonia melihat Rusia memiliki keunggulan aggregare power dibandingkan dengan Estonia. Oleh karena itu, untuk menutupi kekurangan kapabilitas yang dimiliki, Estonia mengandalkan komitmen collective defense dari NATO sebagai bagian dari upaya deterrence terhadap ancaman yang ada. Dituliskan dalam Strategi Pertahanan Estonia bahwa NATO membawa dampak yang cukup signifikan dalam membantu mempertahankan stabilitas status internasional Estonia dan integrasinya ke dalam dunia Barat yang demokratis, serta meningkatkan upaya deterrence dan collective defense yang lebih kredibel (National Defence Strategy Republic of Estonia, 2011). 
Dalam merespon komitmen yang diimplementasikan oleh NATO, Estonia telah meningkatkan 2\% dari GDP mereka untuk alokasi pertahanan (Kaljurand, 2016). Upaya peningkatan kehadiran NATO di wilayah perbatasan dan Eropa Timur dibutuhkan oleh Estonia dalam menghadapi ancaman konvensional yang juga diproyeksikan oleh Rusia. Estonia merasa bahwa deterrence dengan penggunaan kekuatan konvensional dibutuhkan dalam merespon strategi hybrid warfare (Kaljurand, 2016). Startegi hybrid warfare sendiri tidak menutup kemungkinan dalam penggunaan kekerasan dan kekuatan konvensional dan Estonia tidak dapat memprediksi skenario serangan Rusia di masa depan akibat ambiguitas yang diciptakan oleh strategi hybrid warfare. Akibatnya, hal ini juga menjadi sebuah konsekuensi bagi NATO dalam merencanakan pertahanan untuk melindungi negara-negara Baltik seperti Estonia dengan mempertimbangkan rencana strategis dan operasional yang didukung oleh negara-negara anggota.

Selain mendapat dukungan dari NATO, Estonia juga meningkatkan kapabilitas militer mereka dan melengkapi pasukan darat aktif serta pasukan pertahanan tambahan. The Estonian Defence Forces (EDF) sendiri merupakan pasukan yang bertugas aktif di negara0negara Baltik dengan jumlah 3.200 personel-2.800 tentara profesional yang bertugas aktif di militer, 200 tentara angkatan laut, dan 250 pasukan udara (The Military Balance 2016:91). Upaya peningkatan pertahanan konvensional juga ditunjukkan Estonia dalam meningkatkan anggaran pertahanan nasional yang dapat dilihat dari grafik di bawah ini:

Grafik 1

Anggaran Belanja Pertahanan Estonia 2007-2016

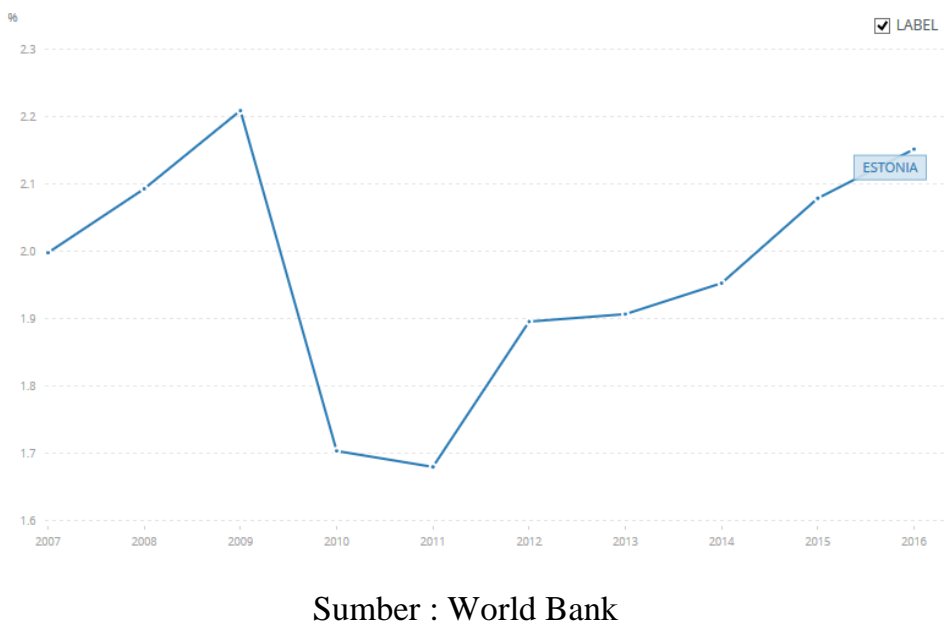


Dari grafik di atas dapat dilihat bahwa tren yang terjadi adalah Estonia selalu meningkatkan pertahanan ketika persepsi terhadap isyarat ancaman meningkat. Seperti di tahun 2007 ketika terjadi peristiwa The Bronze Night, anggaran pertahanan Estonia meningkat menjadi 2,093\% di tahun 2008 dan 2,209\% di tahun 2009. Kemudian setelah sempat mengalami penurunan di tahun sebelumnya, peristiwa aneksasi Krimea kembali menyadarkan Estonia mengenai pentingnya peningkatan pertahanan. Hal itu dimanifestasikan oleh para pembuat keputusan di Estonia dalam meningkatkan pertahanan mereka mencapai 2,079\% di tahun 2015 dan meningkat lagi hingga 2,152 di tahun 2016. Hal itu menunjukkan bahwa Estonia masih berupaya dalam meningkatkan self-defense mereka terhadap ancaman yang ada, khususnya ancaman yang datang dari Rusia. Dan peningkatan anggaran pertahanan juga diimplementasikan sebagai upaya komitmen mereka terhadap NATO yang juga meningkatkan kehadiran mereka di Sayap Timur.

Peningkatan kekuatan konvensional dan kehadiran pasukan NATO menjadi penting ketika Rusia melakukan tindakan-tindakan agresif di perbatasan. Selain itu, Estonia memiliki kapasitas yang lebih besar dalam membantu NATO untuk melakukan upaya penangkalan terhadap ancaman-ancaman yang ada. Untuk menghadapi tantangan ancaman hybrid, tidak cukup terbatas hanya pada peningkatan kekuatan konvensional karena akan menjadi tidak efektif ketika upaya kontra ancaman hybrid hanya difokuskan pada deterrence dan penguatan aliansi. Ancaman hybrid warfare bisa membahayakan semua aspek dan elemen karena sifatnya yang asimetris. Dengan demikian, dibutuhkan pendekatan yang yang lebih menyeluruh dalam level strategis untuk mengurangi pengaruh yang dapat ditimbulkan dari ancaman hybrid.

Pendekatan-pendekatan tersebut diwujudkan oleh Estonia melalui keikutsertaan dalam The European Centre of Excellence for Countering Hybrid Threats sejak April 2017 sebagai upya untuk kontra ancaman hybrid, khususnya yang diterapkan oleh Rusia (Vahtla, 2017). Keikutsertaan Estonia dirasa perlu untuk memperkuat resistensi dengan negara-negara anggota lainnya dalam menghadapi tantangan yang dihadirkan oleh ancaman hybrid. Selain itu, untuk memperkuat keamanan cyber yang merupakan perhatian terbesar Estonia, Estonia dipercaya oleh NATO untuk menjadi markas dari The NATO Cooperative Cyber Defence Centre of Excellence (CCDCOE) yang terletak di Tallin. CCDCOE merupakan pusat keahlian pertahanan cyber multinasional dan interdisipliner. CCDCOE menjadi pusat dalam penyelenggaraan pelatihan teknis pertahanan cyber 
terbesar dan paling kompleks di dunia (CCDCOE, 2017). Di sisi lain, untuk merespon masalah terkait entitas berbahasa Rusia dan ancaman disinformasi, Estonia telah meluncurkan sebuah saluran TV publik berbahasa Rusia yang terpisah pada September 2015 (Praks, 2015:9). Tetapi dalam implementasinya, kebijakan tersebut juga mengalami hambatan karena Estonia sebagai sebuah negara kecil harus melawan ruang informasi yang telah lama diciptakan oleh Rusia bagi entitas berbahasa Rusia di Estonia.

Melawan ancaman dalam penerapan strategi yang diterapkan oleh Rusia memang harus menggunakan berbagai macam pendekatan melihat ancaman hybrid yang bersifat asimetris. Dengan segala kebijakan yang diterapkan oleh Estonia dalam menghadapi ancaman hybrid menunjukkan bahwa para pembuat keputusan telah berada pada tahap penilaian terhadap ancaman yang nyata dan dapat mengganggu stabilitas keamanan di Estonia. Estonia dalam hal ini harus memanfaatkan aliansi yang ada serta bekerjasama dengan NATO dalam membendung ancaman Rusia dan menghindari kelemahan internal yang dapat dimanfaatkan oleh lawan. Dan untuk menghindari hal itu, Estonia harus memiliki tata kelola yang baik bagi pertahanan mereka serta entitas berbahasa Rusia untuk mengurangi pergesekan dan kerentanan terhadap ancaman yang ada. Bagian ini telah membuktikan bahwa Estonia juga melakukan penguatan dan mobilisasi sumber daya serta penerapan kebijakan sebagai bagian dari respon mereka terhadap persepsi ancaman yang muncul akibat tindakan agresif Rusia.

\section{KESIMPULAN}

Tulisan ini telah menganalisa bahwa Rusia merupakan ancaman bagi Estonia berdasarkan persepsi ancaman dari Estonia sendiri. Persepsi ancaman tersebut didorong oleh narasi sejarah yang panjang mengenai hubungan Rusia-Estonia di masa lalu, pengalaman ancaman Estonia, dan ppendapat pengamat kontemporer. Perbedaan pandangan mengenai kemerdekaan menjadikan Rusia memiliki potensi besar untuk menaklukkan kembali negara-negara bekas Soviet. Dalam hal ini, Estonia memiliki nilai politis yang sangat tinggi bagi Rusia. Hal itu juga menjadi bagian dari agendanya untuk meningkatkan pengaruh mereka di kawasan. Estonia yang merupakan anggota NATO dan Uni Eropa, memiliki kecenderungan untuk lebih dekat dengan Barat. Hal itu juga yang mendorong Rusia dalam meningkatkan tindakan agresifnya yaitu untuk membendung pengaruh NATO yang semakin besar. Selain itu narasi sejarah juga berkorelasi dengan entitas berbahasa Rusia di Estonia yang merasa termarjinalkan. Hal itu yang dapat 
dimanfaatkan oleh Rusia untuk menggalang dukungan bagi mereka yang pro-Rusia untuk menciptakan gangguan politik domestik di Estonia. Gangguan tersebut bahkan telah terjadi saat peristiwa the Bronze Night. Selain itu, Rusia telah melakukan tindakan-tindakan asertif lainnya melalui serangan hybrid di Estonia.

Para pembuat keputusan akhirnya mengobservasi isyarat ancaman yang nyata dari strategi hybrid warfare yang dianggap membahayakan negara mereka. Setelah melihat bahwa itu merupakan ancaman, mereka masuk ke dalam tahap penilaian (appraisal) yang diimplementasikan melalui respon untuk mengantisipasi kebahayaan yang ditimbulkan oleh strategi hybrid warfare Rusia. Respon tersebut secara nyata dilaksanakan melalui peningkatan komitmen aliansi dengan NATO dalam membendung ancaman yang ada, peningkatan pertahanan serta kapabilitas militer di Estonia yang dibuktikan dengan peningkatan anggaran pertahanan setiap tahunnya, penguatan cyber defence, serta pendekatan-pendekatan non konvensional lainnya.

Dari tulisan yang telah dikaji oleh penulis, dapat dilihat bahwa ancaman asimetris yang ditimbulkan oleh penerapan strategi hybrid warfare Rusia dapat menyebabkan kehancuran yang tidak kalah besar dengan pendekatan secara konvensional. Di era kontemporer, strategi yang diterapkan oleh lawan untuk mencapai kepentingan mereka semakin tidak dapat diprediksi, pun dengan dinamika konflik di masa depan. Pendekatanpendekatan non tradisional harusnya lebih difokuskan untuk menghadapi ancamanancaman semacam itu. Melihat tren yang terjadi, negara-negara kecil yang tidak memiliki keunggulan aggregate power masih mengandalkan aliansi dalam upaya deterrence mereka. Upaya deterrence tersebut jelas menggunakan pendekatan keamanan tradisional yang masih berbasis mobilisasi pasukan, peningkatan kapabilitas militer, dan penggunaan kekerasan. Perang tidak lagi dilakukan hanya dalam satu battlefield, tetapi seluruh cyberspace, oleh karena itu menjadi penting dalam meningkatkan upaya pertahanan atau kontra ancaman hybrid yang mendasari pada pendekatan non tradisional.

\section{DAFTAR PUSTAKA}

Allison, R. (2014). Russian 'deniable' Intervention in Ukraine: how and why Russia broke the rules. International Affairs, 90: 6, 1255-1297.

Banasik, M. (2016). A Changing Security Paradigm. New Roles for New Actors-The Russian Approach. The Quarterly Journal, 15(4), 31-43.

Bruusgaard, K. V. (2016). Russian Strategic Deterrence. Survival, 58(4), 7-26.

Chivvis, C. S. (2017). Hybrid war: Russian contemporary political warfare. Bulletin of the Atomic Scientists, 73:5, 316-321 
Cohen, R. (1978). Threat Perception in International Crisis. Political Science Quarterly, 93:1.

Grieco, J. M. (1988). Anarchy and the limits of cooperation: A realist critique of the newest liberal institutionalism. International Organization, 42, 485-507.

Grigas, A. (2014). Russia-Baltic Relations after Crimea's Annexation: Reasons for Concern? . Paris: Cicero Foundation Great Debate Paper No. 14/05.

Herzog, S. (2011). Revisiting the Estonian Cyber Attacks: Digital Threats and Multinational Responses. Journal of Strategic Security, 4(2), 49-60.

Hoffman, F. G. (2009). Hybrid Threats: Reconceptualizing the Evolving Character of Modern Conflict. Institute for National Strategic Studies, 240 , 1-8.

Hoffman, F. G. (2009). Hybrid Warfare and Challenges. JFQ(52).

Jakniunaite, D. (2016). Changes in Security Policy and Perceptions of the Baltic States 2014. Journal on Baltic Security, 2(1), 6-34.

Johnson, R. (2018). Hybrid War and Its Countermeasures: A Critique of the Literature. Small Wars \& Insurgencies, 29(1), 141-163.

Lanoszka, A. (2016). Russian hybrid warfare and extended deterrence in eastern Europe. International Affairs, 92: 1, 175-195.

Lanoszka, A., \& Hunzeker, M. A. (2016). Confronting the Anti-Access/Area Denial and Precision Strike Challenge in the Baltic Region. The RUSI Journal, 161:5.

Mastriano, D. (2017). Putin - the masked nemesis of the strategy of ambiguity. Defense \& Security Analysis, 1-9.

Mattiisen, M., Grajewski, P. Z., \& Supinska, A. (2010). Russia's Influence and Presence in Estonia . The Foundation for European Reform.

Michael, R. (2015). NATO and the Ukraine Crisis. American Foreign Policy Interests, 8086.

Monaghan, A. (2014). Putin's Way of War: The 'War' in Russia's 'Hybrid Warfare'. Parameters 45:4, 65-74.

Renz, B. (2016). Russia and 'hybrid warfare'. Contemporary Politics, 1-18.

Ruus, K. (2008). Cyber War I: Estonia Attacked from Russia. European Affairs , 9(1).

Schaub Jr, G., Murphy, M., \& Hoffman, F. G. (2017). Hybrid Maritime Warfare: Building Baltic Resilience. The RUSI Journal, 1162:1, 32-40.

Seely, R. (2017). Defining Contemporary Russian Warfare. The RUSI Journal, 162(1), 5059.

Shea, J. (2015). NATO: the challenges ahead. Global Affairs, 1-8.

Singer, D. J. (1958). Threat Perception and the Armament Tension Dilemma. Journal of Conflict Resolutio, 90-105.

Trimbach, D.J., \& O'Lear, S. (2015). Russians in Estonia: Is Narva the next Crimea?. Eurasian Geography and Economics, 56:5, 493-504

Thornton, R., \& Karagiannis, M. (2016). The Russian Threat to the Baltic States: The Problems of Shaping Local Defense Mechanisms. The Journal of Slavic Military Studies, 29:3, 331-351.

V.N. Yelagin, n. 1.-1. (1994). The Non-Trivial Advice of a Russian from Tallinn. Diplomaticheskii Vestnik(13-14).

Wither, J. K. (2016). Making Sense of Hybrid Warfare. The Quarterly Journal , 15(2), 7387.

Zapfe, M. (2017). Deterrence from the Ground Up: Understanding NATO's Enhanced Forward Presence. Survival, 59:3, 147-160.

About Cyber Defence Centre. (2017). Retrieved April 12, 2018, from The NATO Cooperative Cyber Defence Centre of Excellence : https://ccdcoe.org/about-us.html 
Blank, S. J. (2003). Rethinking Asymmetric Threats. Strategic Studies Institute.

Davis, J. W. (2000). Threats and promises: The pursuit of international influence. Baltimore, MD: Johns Hopkins University Press.

Dougherty, J., \& Kaljurand, R. (2015). Estonia's "Virtual Russian World": The Influence of Russian Media on Estonia's Russian Speaker. Tallin: International Centre for Defence and Security.

Doyle, M. W. (1997). Ways of war and peace: Realism, liberalism, and socialism. New York: Norton.

Estonia, R. o. (2011). National Defence Strategy. Tallin: Estonian Ministry of Defence.

Gerasimov, V. (2013, February 26). The Value of Science is in the Foresight: New Challenges Demand Rethinking the Forms and Methods of Carrying out Combat Operations. Voyenno Promyshlennyy Kurier.

Hoffman, F. G. (2007). Conflict in the 21st Century: The Rise of Hybrid Wars . Virginia: Potomac Institute for Policy Studies.

(Draft Report, April 7, 2015). Hybrid Warfare: NATO's New Strategic Challenge? NATO Parliamentary Assembly Defence and Security Committee.

Knox, M., \& Murray, W. (2001). The Dynamics of Military Revolution 1300-2050. New York: Cambrige University Press.

Lucas, E. (2015). The Coming Storm: Baltic Sea Security Report. Washington, D.C.: Center for European Policy Analysis.

Lucas, E., \& Pomeranze, P. (2016). Winning the Information War: Techniques and Counter-strategies to Russian Propaganda in Central and Eastern Europe. Washington, DC: Center for European Policy Analysis.

Praks, H. (2015). Hybrid or Not: Deterring and Defeating Russia's Ways of Warfare in the Baltics - the Case of Estonia. Rome: NATO Defense College.

Robinson, P. (2008). Dictionary of International Security. Cambridge: Polity.

Samp, L. S., Rathke, J., \& Bell, A. (2016). Perspectives on Security and Strategic Stability . Washington: CSIS.

Smith, J., \& Hendrix, J. (2016). Assured Resolve: Testing Possible Challenges to Baltic Security. Washington, D.C.: Center for New American Century.

The International Institute For Strategic Studies. (2016). The Military Balance 2016. London: Routledge.

The International Institute For Strategic Studies. (2015). The Military Balance 2015. London: Routledge

Zunes, S. (2009). Estonia's Singing Revolution (1986-1991). International Center on Nonviolent Conflict.

Boosting NATO's presence in the east and southeast. (2018, Maret 02). Retrieved April 12, 2018, from North Atlantic Treaty Organization: https://www.nato.int/cps/en/natohq/topics_136388.htm

Evans-Pritchard, A. (2015, Februari 5). Putin could attack Baltic states warns former Nato chief . Retrieved April 10, 2018, from The Telegraph: https://www.telegraph.co.uk/news/worldnews/europe/russia/11393707/Putin-couldattack-Baltic-states-warns-former-Nato-chief.html

Kaljurand, M. (2016, Juli 7). Estonia needs NATO's help against Russia . Retrieved April 12, 2018, from The Washington https://www.washingtonpost.com/opinions/global-opinions/estonia-needs-natoshelp-against-russia/2016/07/07/f0f17d12-43a8-11e6-8856-

f26de2537a9d_story.html?utm_term=.1f3f4f838281 
Laats, J. (2015, Februari 6). Rõivas: Estonia has considered a hybrid war scenario. Retrieved April 10, 2018, from ERR News: https://news.err.ee/115093/roivasestonia-has-considered-a-hybrid-war-scenario

Magazine, B. U. (2016, Desember 11). Russian hybrid war attack on Ukraine "did not come as a complete surprise”. Retrieved April 2018, 10, from Tiny Estonia: Living with the Russian Colossus: http://bunews.com.ua/politics/item/ex-estonian-foreignminister-russian-hybrid-war-attack-on-ukraine-was-not-a-complete-surprise

NATO. (1949, April 4). The North Atlantic Treaty . Retrieved April 10, 2018, from https://www.nato.int/nato_static/assets/pdf/stock_publications/20120822_nato_treat y_en_light_2009.pdf

Obama, B. (2014, September 3). Remarks by President Obama to the People of Estonia. Retrieved April 2018, 2018, from The White House: http://www.whitehouse.gov/the-press-office/2014/09/03/remarks-president-obamapeople-estonia

Population of Tallinn. (2014). Retrieved April 5, 2018, from Statistics Estonia: Database: $<$ http://pub.stat.ee/px-

web.2001/Dialog/varval.asp?ma=PO0222\&ti=POPULATION+BY+SEX\%2C+ET HNIC+NATIONALITY+AND+COUNTY\%2C+1+JANUARY\&path=../I_Databas /Population/01Population_indicators_and_composition/04Population_figure_and_c omposition/\&lang=1>.

Statistical Yearbook of Tallinn 2013 . (2013). Retrieved April 5, 2018, from Tallinn City Government: <http://www.tallinn.ee/g2677s70004>

Vahtla, A. (2017 , April 20). Government to provide money for Estonia to join hybrid threat center. Retrieved April 12, 2018, from ERR News: https://news.err.ee/590937/government-to-provide-money-for-estonia-to-joinhybrid-threat-center

Weitz, R. (2014, November). Countering Russia's Hybrid Threats. Retrieved April 2, 2018, from Diplomaatia No. 135: https://www.diplomaatia.ee/en/article/counteringrussias-hybrid-threats/ 